๑Т. А. Ковальчук, О. Р. Боярчук

Тернопільський національний медичний університет ілені I. Я. Горбачевсъкого МОЗ України

\title{
ПОКАЗНИКИ ДЕЯКИХ ВІТАМІНІВ ГРУПИ В ТА ГОМОЦИСТЕЇНУ У СИРОВАТЦІ КРОВІ ДІТЕЙ ІЗ КАРДІОГЕННИМИ СИНКОПЕ
}

Мета роботи - вивчити показники вітаміну В6, фолієвої кислоти, вітаміну В12 та гомоцистеїну в сироватці крові дітей із кардіогенними синкопе, визначити їх взаємозв'язки із показниками діяльності серцево-судинної системи.

Матеріали та методи. Обстежено 19 дітей із кардіогенними синкопе та 23 практично здорові дитини віком 8-17 років. Кардіогенні синкопе діагностували з використанням критеріїв Європейської асоціації кардіології (2018). Рівні вітамінів В6, B9, В12 та гомоцистеїну в сироватці крові визначали колориметричним методом імуноферментного аналізу з використанням тест-системи Monobind (США). Усім пацієнтам було проведено холтерівське моніторування електрокардіограми та добовий моніторинг артеріального тиску.

Результати дослідження та їх обговорення. Сироваткові рівні вітамінів В6, В9 та В12 у дітей із кардіогенними синкопе не відрізнялися від здорових дітей ( $>>0,05)$. Виявлені кореляційні зв'язки між вітаміном В6 та показниками систолічного артеріального тиску в денний період доби $(r=0,62)$, фолієвою кислотою та кількістю епізодів синкопе в анамнезі $(r=-0,49)$, вітаміном B12 та середньою добовою тривалістю інтервалу QTc $(r=0,49)$ і показником варіабельності серцевого ритму LF/ $\mathrm{HF}(\mathrm{r}=0,46) €$ свідченням можливої ролі даних вітамінів у патогенезі кардіогенних синкопе $(\mathrm{p}<0,05)$. Порівняно 3 контрольною групою, у дітей із кардіогенними синкопе спостерігався достовірно вищий показник сироваткового гомоцистеїну $(15,30 \pm 1,23$;

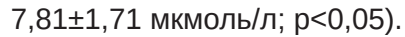

Висновки. Кардіогенні синкопе у дітей характеризуються високими показниками гомоцистеїну на тлі референтних значень вітамінів В6, В9, В12. Поширеність гіпергомоцистеїнемії у групі кардіогенних синкопе становить 72,2%.

Ключові слова: вітамін В6; фолієва кислота; вітамін В12; гомоцистеїн; кардіогенні синкопе; діти.

ПОКАЗАТЕЛИ НЕКОТОРЫХ ВИТАМИНОВ ГРУППЫ В И ГОМОЦИСТЕИНА В СЫВОРОТКЕ КРОВИ ДЕТЕЙ С КАРДИОГЕННЫМИ СИНКОПЕ

Цель работы - изучить показатели витамина В6, фолиевой кислоты, витамина В12 и гомоцистеина в сыворотке крови детей с кардиогенным синкопе, определить их взаимосвязи с показателями деятельности сердечно-сосудистой системы.

Материалы и методы. Обследовано 19 детей с кардиогенным синкопе и 23 практически здоровых ребенка в возрасте 8-17 лет. Кардиогенные синкопе диагностировали с использованием критериев Европейской ассоциации кардиологии (2018). Уровни витаминов B6, В9, В12 и гомоцистеина в сыворотке крови определяли колориметрическим методом иммуносрерментного анализа с использованием тест-системы Monobind (США). Всем пациентам было проведено холтеровское мониторирование электрокардиограммы и суточный мониторинг артериального давления.

Результаты исследования и их обсуждение. Сывороточные уровни витаминов В6, В9 и В12 у детей с кардиогенным синкопе не отличались от здоровых детей ( $>0,05)$. Выявленные корреляционные связи между витамином В6 и показателями систолического артериального давления в дневное время суток $(r=0,62)$, фолиевой кислотой и количеством эпизодов синкопе в анамнезе $(r=-0,49)$, витамином B12 и средней суточной продолжительностью интервала QTc $(r=0,49)$ и показателем вариабельности сердечного ритма LF/HF $(r=0,46)$ свидетельствуют о возможной роли данных витаминов в патогенезе кардиогенных синкопе $(p<0,05)$. По сравнению с контрольной группой, у детей с кардиогенным обмороком наблюдался достоверно более высокий показатель сывороточного гомоцистеина $(15,30 \pm 1,23 ; 7,81 \pm 1,71$ мкмоль/л; р<0,05).

Выводы. Кардиогенные синкопе у детей характеризуются высокими показателями гомоцистеина на фроне ресрерентных значений витаминов В6, В9, В12. Распространенность гипергомоцистеинемии в группе кардиогенных синкопе составляет 72,2\%.

Ключевые слова: витамин В6; фолиевая кислота; витамин В12; гомоцистеин; кардиогенный обморок; дети.

VITAMINS B AND HOMOCYSTEINE IN THE SERUM OF CHILDREN WITH CARDIAC SYNCOPE

The aim of the study - to investigate vitamin B6, folic acid, vitamin B12 and homocysteine levels in the serum of children with cardiac syncope and to determine their relationships with indicators of cardiovascular system functioning.

Materials and Methods. 19 children with cardiac syncope and 23 practically healthy children aged 8-17 years were examined. Cardiac syncope was diagnosed using criteria of the European Society of Cardiology (2018). Serum vitamins B6, B9, B12 and homocysteine levels were determined by colorimetric enzyme-linked immunosorbent assay using the Monobind test system (USA). 24-hour Holter monitoring and 24-hour ambulatory blood pressure monitoring were provided for all patients.

Results and Discussion. Serum vitamins B6, B9 and B12 levels in children with cardiac syncope were not differ from healthy children ( $p>0.05$ ). The correlations between vitamin B6 and systolic blood pressure during day $(r=0.62)$, folic acid and the number of syncope episodes in the anamnesis $(r=-0.49)$, vitamin B12 and the average duration of QTc interval $(r=0.49)$, vitamin B12 and the heart rate variability parameter $\mathrm{LF} / \mathrm{HF}(\mathrm{r}=0.46)$ are evidence of possible role of these vitamins in the pathogenesis of cardiac syncope $(p<0.05)$. Compared with the control group, children with cardiac syncope had a significantly higher rate of serum homocysteine $(15.30 \pm 1.23 ; 7.81 \pm 1.71 \mu \mathrm{mol} / / ; p<0.05)$.

Conclusions. Cardiac syncope in children is characterized by high homocysteine level on the background of reference vitamins B6, B9, B12 values. The prevalence of hyperhomocysteinemia is $72.2 \%$ in the group of cardiac syncope.

Key words: vitamin B6; folic acid; vitamin B12; homocysteine; cardiac syncope; children. 
ВСТУП. Синкопальні стани є доволі поширеною проблемою та виникають приблизно у 50 \% населення в цілому. За різними даними, орієнтовно 15-25 \% дітей переживають щонайменше один епізод синкопе до досягнення ними дорослого віку $[1,2]$. Синкопе можуть спричиняти порушення кровообігу чи метаболізму, психіатричних або нейрофрізіологічних процесів, зумовлюючи таким чином їх доброякісний чи смертельно небезпечний перебіг. Найнебезпечнішим різновидом синкопе є кардіогенні синкопе (KC), які складають 10 \% від усіх синкопальних станів у дітей [3] та виникають внаслідок раптового зниження серцевого викиду, що, в свою чергу, приводить до розвитку мозкової гіпоперфузії та непритомності [4]. Тривалі епізоди зниження серцевого викиду можуть призвести до раптової смерті або неврологічних пошкоджень внаслідок тривалої ішемії, що робить розпізнавання цього виду синкопе актуальною та вкрай важливою проблемою сучасної педіатрії [1].

Пошук нових патофрізіологічних механізмів розвитку синкопе дозволить не лише краще зрозуміти природу непритомності, але й віднайти значно ефективніші методи лікування даної патології. Так, є обґрунтовані докази впливу на розвиток вазовагальних синкопе таких нейрогормонів, як адреналін, норадреналін та вазопресин [5]. У пацієнтів із синкопе часто спостерігають дефіцит вітаміну $\mathrm{D}$, що зумовлено незрозумілим досі його прямим або ж опосередкованим впливом на розвиток вегетативної дисфункції [6, 7]. До того ж, у дітей із вазовагальними синкопе та синдромом постуральної тахікардії реєструються дефіцит вітамінів групи В та гіпергомоцистеїнемія [8, 9].

МЕТА ДОСЛІДЖЕННЯ - вИвчити показНИки вітаміну В6, фролієвої кислоти, вітаміну В12 та гомоцистеїну в сироватці крові дітей із КС, визначити їх взаємозв'язки із показниками діяльності серцево-судинної системи.

МАТЕРІАЛИ ТА МЕТОДИ. Для ДОсягнення метИ дослідження обстежено 125 дітей віком 8-17 років із щонайменше одним епізодом синкопе протягом місяця до моменту їх звернення за медичною допомогою. Синкопе діагностували з використанням критеріїв Європейської асоціації кардіології (2018) [10] - наявність транзиторної втрати свідомості, що характеризується раптовим початком, короткою тривалістю та спонтанним повним видужанням. Пацієнти із симптомами транзиторної втрати свідомості в результаті травми голови в даному дослідженні участі не брали. Усім пацієнтам із синкопе проводили ретельний збір скарг та анамнезу (вік на момент першої втрати свідомості; фрактори, які передували первинному синкопе; частоту, періодичність, стереотипність та серійність нападів; тригерні фактори; методи, які дозволяють попередити втрату свідомості; клінічні прояви в пресинкопальному, синкопальному та постсинкопальному періодах; параепілептичні френомени; спадкові фрактори), фрізикальне обстеження, у т.ч. тест активного ортостазу [11], електрокардіографію (ЕКГ) в 12-ти відведеннях, ехокардіографію, електроенцефалографрію. За результатами проведених досліджень 125 дітей із синкопе, у 19 із них було діагностовано КС.

Критерії включення у групу КС:

- синкопе виникає під час навантажень або в положенні лежачи;

- типові патологічні зміни на ЕКГ (біфасцикулярна блокада; інші порушення внутрішньошлуночкової про- відності з тривалістю QRS>0,12 c; атріовентрикулярна блокада II-III ступенів; персистуюча синусова брадикардія або фрібриляція передсердь із чСС<50 уд/хв; повторні епізоди синоатріальної блокади; паузи синусового ритму більше 3 с в активний період при відсутності фрізичних навантажень; пароксизмальна суправентрикулярна або вентрикулярна тахікардія; синдроми преекзитації шлуночків; синдром подовженого або вкороченого інтервалу Q-T; синдром ранньої реполяризації шлуночків; синдром Бругада; аритмогенна кардіоміопатія правого шлуночка з епсилон-хвилями та негативними зубцями Т в правих відведеннях; гіпертрофічна кардіоміопатія з гіпертрофрією лівого шлуночка) і/або ехокардіограмі (структурні захворювання серця) [10];

- не менше одного епізоду синкопе впродовж останнього місяця;

- нормальна реакція на тест активного ортостазу;

- відсутність іншої очевидної етіології синкопе;

- відсутність супутніх гострих або хронічних захворювань, включаючи артеріальну гіпертензію, надмірну масу або ожиріння, анемію, гіпотиреоз та порушення орункції нирок.

До контрольної групи увійшли 23 практично здорові дитини аналогічного віку, які не мали скарг, анамнестичних даних та клінічних ознак, що свідчили б про наявність будь-якого гострого чи хронічного захворювання.

У даному дослідженні респонденти брали участь лише після підписання інформованої згоди дітьми та їх батьками. У роботі дотримані етичні принципи щодо людей, які виступають суб'єктами дослідження, з урахуванням основних положень GCP ICH і Гельсінської декларації Всесвітньої медичної асоціації з біомедичних досліджень, у яких людина виступає їх об'єктом (World Medical Association Declaration of Helsinki, 1964, 2000, 2008), Конвенції Ради Європи про права людини й біомедицину (2007).

Зразки венозної крові у кількості 5 мл були відібрані 3 передпліччя усіх учасників дослідження у період між 08.00 та 11.00 год. Впродовж наступних 30 хв цільну кров центрифугували зі швидкістю 3000 об/хв протягом 5 хв. Отримані зразки сироватки заморожували до мінус $80{ }^{\circ} \mathrm{C}$ та зберігали не більше 20 місяців. Рівні піридоксину (вітамін B6), фолатів, кобаламіну (вітамін В12) та гомоцистеїну в сироватці крові визначали колориметричним методом імуноферментного аналізу (ІФА) з використанням тестсистеми Monobind (США) у Тернопільському національному медичному університеті імені І. Я. Горбачевського MO3 України. Гіпергомоцистеїнемію визначали як сироватковий гомоцистеїн вище 95-го перцентиля відповідно до віку дитини [12].

Усім дітям було проведено холтерівське моніторування ЕКГ (ХМЕКГ) за допомогою триканального добового монітора електрокардіосигналів SDM3 (Україна). Аналіз основних показників ХМЕКГ здійснювали 3 використанням програмного забезпечення (Ver 8.4.013) після мануального видалення із запису усіх артефактів. Часові характеристики варіабельності серцевого ритму вивчали за допомогою показників SDANN (стандартне відхилення середніх інтервалів RR у всіх 5-хвилинних сегментах запису), RMSSD (стандартне середньоквадратичне відхилення різниці послідовних інтервалів RR), pNN50 (відсоток послідовних інтервалів RR, різниця між 
якими перевищує 50 мс). Частотні характеристики варіабельності серцевого ритму оцінювали з використанням TP (загальна потужність спектра у досліджуваному діапазоні), VLF (середнє значення потужності спектра на частоті менше 0,05 Гц), LF (середнє значення спектра низької частоти з потужністю 0,05-0,15 Гц), HF (середнє значення потужності спектра на частоті 0,15-0,4 Гц), LF/ HF (співвідношення середніх значень низькочастотного і високочастотного компонентів варіабельності) [13].

Добовий моніторинг артеріального тиску (ДМАТ) проводили за допомогою осцилометричного монітора ВАТ41-2 (Україна) із використанням манжети відповідного розміру протягом 24 год за умов звичайного функціонування. Для інтерпретації результатів ДМАТ застосовували рекомендації Європейського товариства гіпертензії 2014 року [14].

Статистичний аналіз отриманих результатів здійснювали за допомогою статистичного пакета програми SPSS 12.0 для Windows. Результати вимірювань представлені як середнє арисрметичне (M) \pm середнє квадратичне відхилення $(\mathrm{m})$. Для порівняння двох незалежних вибірок використовували U-критерій Манна-Уітні. Зіставлення частотних характеристик якісних показників здійснювали 3 використанням критерію $\chi^{2}$. Для з'ясування зв'язку між досліджуваними показниками проводили кореляційний аналіз із розрахунком коефіцієнта кореляції Спірмена. Значимість відмінностей брали за вірогідну при р<0,05.

РЕЗУЛЬТАТИ ДОСЛІДЖЕННЯ ТА ЇХ ОБГОВОРЕННЯ. У 8 (42,1 \%) дітей основної групи було виявлено лише одну типову патологічну зміну на ЕКГ чи ехокардіографрії, що приводить до розвитку КС, тоді як у 11 (57,9 \%) пацієнтів їх було 2 та більше. Порушення серцевого ритму та провідності мали місце у 18 (94,7 \%) із 19 обстежених дітей та характеризувалися такими змінами: пароксизмальна суправентрикулярна тахікардія (47,4 \%), синдроми преекзитації шлуночків (31,6\%), синоатріальна блокада II ступеня (21,1 \%), повна блокада правої ніжки пучка Гіса (10,5 \%), біфасцикулярна блокада (5,3 \%), атріовентрикулярна блокада II-III ступенів (10,5\%), синдром подовженого інтервалу QT (5,3 \%), синдром слабкості синусового вузла (5,3 \%), синдром Бругада (5,3 \%), синдром ранньої реполяризації шлуночків (5,3 \%). В однієї дитини (5,3 \%) мала місце уроджена вада серця - десект міжшлуночкової перетинки 3 легеневою гіпертензією, мітральною та аортальною недостатністю. Жодної достовірної різниці між віком, статтю та індексом маси тіла (IMT) у дітей основної та контрольної груп виявлено не було. До того ж, частота серцевих скорочень (ЧСС), рівні систолічного артеріального тиску (САТ), діастолічного артеріального тиску (ДАТ), гемоглобіну та еритроцитів у пацієнтів двох груп теж не відрізнялися (табл. 1). Це дозволило виключити вплив факторів віку, статі, надлишкової маси чи ожиріння, артеріальної гіпертензії й анемії на сироваткові показники вітамінів В6 і В12, фолієвої кислоти та гомоцистеїну.

За результатами даного дослідження було встановлено, що у дітей із КС сироваткові рівні вітаміну В6 і В12 та фолієвої кислоти достовірно не відрізняються від таких, що у здорових дітей (табл. 1). Наскільки нам відомо, до сьогодні не було проведено жодних досліджень із вивчення рівнів цих вітамінів у сироватці крові дітей із КС. Втім, окремі дослідження звертають увагу на десріцит

Таблиця 1. Демографічні, клінічні та біохімічні характеристики обстежених дітей

\begin{tabular}{|c|c|c|c|}
\hline Характеристики & $\begin{array}{c}\text { Група КС } \\
(n=19)\end{array}$ & $\begin{array}{c}\text { Контрольна група } \\
(n=23)\end{array}$ & $\mathrm{p}$ \\
\hline Вік, роки & $13,68 \pm 0,64$ & $12,83 \pm 0,50$ & 0,105039 \\
\hline Хлоці/дівчата, n & $13 / 6$ & $9 / 14$ & 0,058500 \\
\hline IMT, кг/M² & $20,67 \pm 1,37$ & $18,96 \pm 0,54$ & 0,854995 \\
\hline Вік на момент першого синкопе, роки & $11,84 \pm 0,65$ & - & - \\
\hline Кількість епізодів синкопе за життя, n & $5,37 \pm 1,67$ & - & - \\
\hline Тривалість останнього епізоду пресинкопе, хв & $0,68 \pm 0,25$ & - & - \\
\hline Тривалість останнього епізоду синкопе, хв & $1,47 \pm 0,33$ & - & - \\
\hline Тривалість останнього епізоду постсинкопе, хв & $148,20 \pm 52,53$ & - & - \\
\hline ЧСС у положенні лежачи, мм рт. ст. & $68,32 \pm 2,60$ & $72,43 \pm 1,27$ & 0,218111 \\
\hline САТ у положенні лежачи, мм рт. ст. & $106,60 \pm 2,48$ & $107,00 \pm 1,12$ & 0,732606 \\
\hline ДАТ у положенні лежачи, мм рт. ст. & $66,05 \pm 1,69$ & $66,09 \pm 1,33$ & 0,987321 \\
\hline Гемоглобін, г/л & $138,39 \pm 4,89$ & $13,52 \pm 1,22$ & 0,424630 \\
\hline Еритроцити, х1012/л & $4,54 \pm 0,20$ & $4,58 \pm 0,67$ & 0,662658 \\
\hline Вітамін В6, мкг/л & $14,68 \pm 1,58$ & $16,11 \pm 5,53$ & 0,407945 \\
\hline Фолієва кислота, мкг/л & $4,08 \pm 0,37$ & $4,71 \pm 1,73$ & 0,231970 \\
\hline Вітамін В12, нг/л & $393,41 \pm 21,92$ & $447,28 \pm 22,70$ & 0,159884 \\
\hline Гомоцистеїн, мкмоль/л & $15,30 \pm 1,23$ & $7,81 \pm 1,71$ & $0,000001^{*}$ \\
\hline Гіпергомоцистеїнемія, n (\%) & $13(72,22)$ & $1(4,35)$ & $0,000000^{*}$ \\
\hline
\end{tabular}

Примітка. * - позначені статистично значимі кореляції (р<0,05). 
піридоксину і кобаламіну в крові дітей із вазовагальними синкопе та їх роль у розвитку вегетативної диссрункції $[9,15]$. В одному із спостережень у дорослих було показано, що десріцит вітаміну В12 спостерігається у 33 \% пацієнтів із серцево-судинними захворюваннями та не корелює із рівнем гомоцистеїну крові [16]. До того ж, у дорослих із серцевою недостатністю достовірно частіше реєструють дефріцит кобаламіну порівняно зі здоровими [17], а у пацієнтів із фрібриляцією передсердь - дефіцит піридоксину [18].

Порівняно з контрольною групою, у дітей із КС спостерігався достовірно вищий показник сироваткового гомоцистеїну. Поширеність гіпергомоцистеїнемії у групі КС склала 72,2 \%. Як відомо, гіпергомоцистеїнемія виникає внаслідок порушення обміну гомоцистеїну та пов'язана із різними патологічними станами, включаючи серцево-судинні та нейродегенеративні захворювання [12]. В одному із нещодавніх досліджень були верифріковані достовірно високі рівні гомоцистеїну у дітей із синдромом постуральної тахікардії та висунуто гіпотезу, що гіпергомоцистеїнемія може відігравати роль у розвитку синкопе шляхом підвищеної чутливості барорецепторного рефрлексу [8]. Однією із причин гіпергомоцистеїнемії є недостатній рівень піридоксину, фолатів та кобаламіну, які $€$ косракторами та косубстратами в метаболізмі гомоцистеїну. Окрім цього, поліморфізм генів, що кодують срерменти, які беруть безпосередню участь у метаболізмі гомоцистеїну, теж впливає на показник гомоцистеїну крові [19]. На додачу, рівень гомоцистеїну зростає з віком та $€$ дещо вищим у хлопців порівняно 3 дівчатами [19]. У нашому дослідженні показник гомоцистеїну в сироватці крові від віку та статі пацієнтів із КС не залежав (табл. 2).

Кореляційний аналіз основних клінічних показників та сироваткових рівнів вітамінів групи В та гомоцистеїну дозволив виявити такі особливості КС (табл. 2). Сироваткова концентрація фолієвої кислоти обернено пропорційно залежала від віку дітей із КС та кількості епізодів синкопе в анамнезі. Зниження показника вітаміну В6 та зростання гомоцистеїну асоціювалося зі зменшенням САТ у положенні лежачи.

Окрім цього, середня добова тривалість інтервалу QTc, за даними ХМЕКГ, зменшувалася зі зниженням сироваткового рівня вітаміну В12, а зростання сироваткового рівня гомоцистеїну супроводжувалося зменшенням відсотка тривалості епізодів тахікардії за добу в дітей із КС (табл. 3, 4). Окремі наукові праці акцентують увагу

Таблиця 2. Кореляційна матриця основних клінічних показників КС та сироваткових рівнів вітаміну В6, фолієвої кислоти, вітаміну В12 та гомоцистеїну

\begin{tabular}{|c|c|c|c|c|}
\hline Показник & Вітамін B6 & Фолієва кислота & Вітамін В12 & Гомоцистеїн \\
\hline Вік & 0,0943 & $-0,4990^{*}$ & $-0,1813$ & 0,1268 \\
\hline Стать & 0,0681 & $-0,1590$ & $-0,0454$ & $-0,1817$ \\
\hline IMT & 0,2156 & $-0,3312$ & $-0,4551$ & $-0,2053$ \\
\hline Вік першого синкопе & $-0,1562$ & 0,0545 & $-0,0576$ & 0,3566 \\
\hline Кількість епізодів синкопе за життя & 0,1392 & $-0,4861^{*}$ & $-0,1392$ & $-0,0105$ \\
\hline Тривалість останнього епізоду пресинкопе & 0,0834 & 0,0697 & 0,2228 & $-0,1246$ \\
\hline Тривалість останнього епізоду синкопе & $-0,0601$ & $-0,1899$ & 0,0875 & 0,1962 \\
\hline Тривалість останнього епізоду постсинкопе & $-0,1169$ & 0,1357 & $-0,1817$ & 0,2224 \\
\hline ЧСС у положенні лежачи & 0,2226 & 0,1418 & $-0,0901$ & $-0,1004$ \\
\hline САТ у положенні лежачи & $0,6244^{*}$ & $-0,0657$ & 0,0339 & $-0,6520^{*}$ \\
\hline ДАТ у положенні лежачи & 0,3442 & 0,0196 & $-0,2786$ & $-0,3475$ \\
\hline
\end{tabular}

Примітка. * - позначені статистично значимі кореляції ( $p<0,05)$.

Таблиця 3. Результати кореляційного аналізу параметрів ХМЕКГ та вітамінів групи В і гомоцистеїну в дітей із КС

\begin{tabular}{|l|c|c|c|c|}
\hline \multicolumn{1}{|c|}{ Параметр } & Вітамін B6 & Фолієва кислота & Вітамін В12 & Гомоцистеїн \\
\hline \multicolumn{1}{|c|}{1} & 2 & 3 & 4 & 5 \\
\hline Середня добова ЧСС & 0,3004 & $-0,1888$ & $-0,1213$ & $-0,2930$ \\
\hline Тривалість епізодів тахікардії за добу, \% & 0,3872 & $-0,3137$ & 0,0808 & $-\mathbf{0 , 4 8 2 8 *}$ \\
\hline Тривалість епізодів брадикардії за добу, \% & 0,0737 & 0,1125 & 0,3182 & $-0,0310$ \\
\hline Тривалість епізодів аритмії за добу, \% & $-0,2645$ & 0,2751 & $-0,0599$ & 0,3210 \\
\hline Середня добова тривалість інтервалу PQ, мс & $-0,0363$ & 0,0363 & 0,3090 & 0,0181 \\
\hline Середня добова тривалість інтервалу QTс, мс & 0,1520 & 0,3458 & $\mathbf{0 , 4 8 8 0}$ & $-0,2967$ \\
\hline SDANN, мс & $-0,4166$ & 0,2549 & 0,2328 & 0,0808 \\
\hline RMSSD, мс & $-0,4093$ & 0,3259 & 0,0735 & 0,4436 \\
\hline
\end{tabular}


Продовження табл. 3.

\begin{tabular}{|c|c|c|c|c|}
\hline 1 & & ? & & \\
\hline pNN50, \% & -0.4365 & 0.3825 & 0.1949 & 0.2795 \\
\hline $\mathrm{TP}, \mathrm{MC}^{2}$ & $-0,3308$ & 0,3921 & 0,0661 & 0,2867 \\
\hline VLF, $\mathrm{MC}^{2}$ & $-0,0098$ & 0,0882 & $-0,1911$ & 0,1151 \\
\hline LF, MC ${ }^{2}$ & $-0,1042$ & 0,1679 & 0,0220 & 0,0232 \\
\hline $\mathrm{HF}, \mathrm{MC}^{2}$ & $-0,1470$ & 0,0416 & $-0,0857$ & 0,1519 \\
\hline LF/HF, y. о. & 0,3534 & 0,0098 & $0,4581^{*}$ & $-0,3386$ \\
\hline
\end{tabular}

Примітка. * - позначені статистично значимі кореляції ( $<<0,05)$.

Таблиця 4. Кореляційна матриця окремих параметрів ДМАТ та вітамінів групи В і гомоцистеїну в групі КС

\begin{tabular}{|c|c|c|c|c|}
\hline Показник & Вітамін В6 & Фолієва кислота & Вітамін В12 & Гомоцистеїн \\
\hline Середній САТ день & $0,5607^{*}$ & $-0,1738$ & $-0,1583$ & $-0,4624^{*}$ \\
\hline Середній ДАТ день & 0,3616 & $-0,2155$ & $-0,0445$ & $-0,3730$ \\
\hline Середній САТ ніч & 0,0735 & $-0,3148$ & $-0,3459$ & $-0,1128$ \\
\hline Середній ДАТ ніч & 0,2539 & $-0,2622$ & $-0,2351$ & $-0,2903$ \\
\hline Вище за ліміт САТ день & $0,7792^{*}$ & $-0,0124$ & 0,0966 & $-0,6794^{*}$ \\
\hline Вище за ліміт ДАТ день & 0,2426 & $-0,1389$ & 0,1690 & $-0,2156$ \\
\hline Вище за ліміт САТ ніч & 0,2845 & $-0,0564$ & $-0,0292$ & $-0,4079$ \\
\hline Вище за ліміт ДАТ ніч & 0,1932 & $-0,0685$ & $-0,2742$ & $-0,1963$ \\
\hline Навант тиском САТ день & $0,7464^{*}$ & $-0,0530$ & $-0,0148$ & $-0,6613^{*}$ \\
\hline Навант тиском ДАТ день & 0,3408 & $-0,2293$ & 0,0895 & $-0,3359$ \\
\hline Навант тиском САТ ніч & 0,3823 & $-0,2331$ & $-0,1767$ & $-0,3647$ \\
\hline Навант тиском ДАТ ніч & 0,2263 & $-0,2226$ & $-0,3210$ & $-0,2140$ \\
\hline Площа під гр САТ день & $0,5553^{*}$ & $-0,0646$ & $-0,0819$ & $-0,4708^{*}$ \\
\hline Площа під гр ДАТ день & 0,2066 & $-0,1423$ & 0,0259 & $-0,2005$ \\
\hline Площа під гр САТ ніч & $0,5252^{*}$ & $-0,2825$ & $-0,0796$ & $-0,3335$ \\
\hline Площа під гр ДАТ ніч & 0,3220 & $-0,1073$ & $-0,0863$ & $-0,1998$ \\
\hline
\end{tabular}

Примітка. * - позначені статистично значимі кореляції $(p<0,05)$.

на тому, що варіабельність серцевого ритму є одним із маркерів одужання у дітей із критичними станами [20]. У нашому дослідженні зниження вітаміну В12 у сироватці крові характеризувалося зниженням показника LF/HF, що $€$ свідченням ймовірного впливу цього вітаміну на дисбаланс симпатичної і парасимпатичної нервової системи та патологічну регуляцію серцевого ритму в дітей із КС [13]. Sucharita S. та ін. показали, що метилмалонова кислота $€$ кращим маркером діагностики десіциту вітаміну В12 на тканинному рівні, бо, порівняно з кобаламіном, суттєво асоціюється із показниками варіабельності серцевого ритму [21].

ВИСНОВКИ. 1. Порівняно зі здоровими дітьми, у дітей із КС реєструються достовірно вищі показники гомоцистеїну на тлі рефрерентних значень піридоксину, фолієвої кислоти та кобаламіну. Поширеність гіпергомоцистеїнемії у групі КС становить 72,2 \%.

2. Виявлені кореляційні зв'язки між вітаміном В6 та показниками САТ в денний період доби, фролієвою кислотою та кількістю епізодів синкопе в анамнезі, вітаміном В12 та середньою добовою тривалістю інтервалу QTC і показником варіабельності серцевого ритму LF/HF $€$ свідченням можливої ролі даних вітамінів у патогенезі КС.

ПЕРСПЕКТИВИ ПОДАЛЬШИХ ДОСЛІДЖЕНЬ. ДаНР спостереження виконано вперше у групі дітей із КС із залученням доволі невеликої кількості пацієнтів, а тому подальші дослідження є необхідними. Не менш важливим є і питання вивчення есрективності використання препаратів вітамінів В6, В12 та фролієвої кислоти з метою корекції гіпергомоцистеїнемії у дітей із КС та профрілактики повторних епізодів синкопе. 


\section{СПИСОК ЛІТЕРАТУРИ}

1. Cannon B. Syncope / B. Cannon, P. Wackel // Pediatr. Rev. - 2016. - Vol. 37 (4). - P. 159-168.

2. Scott W. A. Evaluating the child with syncope / W. A. Scott // Pediatr. Ann. - 1991. - Vol. 20 (7). - P. 350-351.

3. Mohanty S. Clinico-etiological profile of pediatric syncope: a single center experience / S. Mohanty, C. P. R. Kumar, S. M. Kaku // Indian Pediatr. - 2021. - Vol. 58 (2). - P. 134-136.

4. The evaluation and management of pediatric syncope / B. A. Jeffrey, M. Willis, H. Lancaster [et al.] // Pediatr. Neurol. 2016. - Vol. 55. - P. 6-13.

5. Neurohormones in the pathophysiology of vasovagal syncope in adults / D. G. Benditt, J. G. van Dijk, D. Krishnappa [et al.] // Front. Cardiovasc. Med. - 2020. - Vol. 7. - P. 76.

6. Vitamin D deficiency and vasovagal syncope in children and adolescents / Q. Zhang, Y. Sun, C. Zhang [et al.] // Front. Pediatr. - 2021. - Vol. 9. - P. 575923.

7. Kovalchuk $\mathrm{T}$. The role of vitamin $\mathrm{D}$ deficiency in the origin of vasovagal syncope in childhood / T. Kovalchuk, O. Boyarchuk // Int. J. Endocrinol. - 2020. - Vol. 16 (3). - P. 231-236.

8. Plasma homocysteine level in children with postural tachycardia syndrome / Y. Li, B. He, H. Li [et al.] // Front. Pediatr. - 2018. - Vol. 6. - P. 375.

9. Pektas, A. Serum vitamin B-12 in children presenting with vasovagal syncope / A. Pektas, R. Koken, H. B. Koca // Asia Pac. J. Clin. Nutr. - 2018. - Vol. 27 (1). - P. 176-181.

10. 2018 ESC Guidelines for the diagnosis and management of syncope / M. Brignole, A. Moya, F. J de Lange [et al.] // Eur. Heart J. - 2018. - Vol. 39 (21). - P. 1883-1948.

11. Japanese clinical guidelines for juvenile orthostatic dysregulation version 1 / $\mathrm{H}$. Tanaka, Y. Fujita, Y. Takenaka [et al.] // Pediatrics international. - 2009. - Vol. 51 (1). - P. 169-179.

12. Total homocysteine, folate, and cobalamin, and their relation to genetic polymorphisms, lifestyle and body mass index in healthy children and adolescents / M. Huemer,

\section{REFERENCES}

1. Cannon, B., \& Wackel, P. (2016). Syncope. Pediatr. Rev., 37 (4), 159-168. DOI: 10.1542/pir.2014-0109.

2. Scott, W.A. (1991). Evaluating the child with syncope. Pediatr. Ann., 20 (7), 350-351. DOI: 10.3928/0090-4481-19910701-08.

3. Mohanty, S., Kumar, C.P.R., \& Kaku, S.M. (2021). Clinico-etiological profile of pediatric syncope: a single center experience. Indian Pediatr., 58 (2), 134-136.

4. Anderson, J.B., Willis, M., Lancaster, H., Leonard, K., \& Thomas, C. (2016). The evaluation and management of pediatric syncope. Pediatr. Neurol., 55, 6-13. DOI: 10.1016/j. pediatrneurol.2015.10.018.

5. Benditt, D.G., van Dijk, J.G., Krishnappa, D., Adkisson, W.O., \& Sakaguchi, S. (2020). Neurohormones in the pathophysiology of vasovagal syncope in adults. Front. Cardiovasc. Med., 7, 76. DOI: 10.3389/fcvm.2020.00076.

6. Zhang, Q., Sun, Y., Zhang, C., Qi, J., \& Du, J. (2021). Vitamin D deficiency and vasovagal syncope in children and adolescents. Front. Pediatr., 9, 575923. DOI: 10.3389/ fped.2021.575923.

7. Kovalchuk, T., \& Boyarchuk, O. (2020). The role of vitamin $D$ deficiency in the origin of vasovagal syncope in childhood. Int. J. Endocrinol., 16 (3), 231-236. DOI: 10.22141/22240721.16.3.2020.205272.

8. Li, Y., He, B., Li, H., Zhang, Q., Tang, C., Du, J., \& Jin, H. (2018). Plasma homocysteine level in children with postural tachycardia syndrome. Front. Pediatr., 6, 375. DOI: 10.3389/ fped.2018.00375.
K. Vonblon, M. Fodinger [et al.] // Pediatr. Res. - 2006. Vol. 60 (6). - P. 764-769.

13. Бережний В. В. Застосування визначення варіабельності серцевого ритму у дітей / В. В. Бережний, І. В. Романкевич // Современная педиатрия. - 2015. - № 1 (65). - С. 87-91.

14. European Society of Hypertension practice guidelines for ambulatory blood pressure monitoring / G. Parati, G. Stergiou, E. O'Brien [et al.] // J. Hypertens. - 2014. - Vol. 32 (7). - P. 1359-1366.

15. Ковальчук Т. А. Особливості профрілю вітаміну В6 у дітей та підлітків із вазовагальними синкопе / Т. А. Ковальчук // Сучасна педіатрія. Україна. - 2020. - № 4 (108). - С. 61-66.

16. The predictive value of vitamin B12 concentrations and hyperhomocysteinaemia for cardiovascular disease / M. G. van Oijen, R. J. Laheij, J. B. Jansen, F. W. Verheugt // Neth. Heart J. - 2007. - Vol. 15 (9). P. 291-294.

17. Methylmalonic acid and vitamin B12 in patients with heart failure / K. Polytarchou, Y. Dimitroglou, D. Varvarousis [et al.] // Hellenic J. Cardiol. - 2020. - Vol. 61 (5). - P. 330-337.

18. Hyperhomocysteinemia and vitamin B6 deficiency: new risk markers for nonvalvular atrial fibrillation? / R. Marcucci, I. Betti, E. Cecchi [et al.] // Am. Heart J. - 2004. - Vol. 148 (3). - P. 456-461.

19. Homocysteine metabolism in children and adolescents: influence of age on plasma biomarkers and correspondent genotype interactions / H. Caldeira-Araújo, R. Ramos, C. Florindo [et al.] // Nutrients. - 2019. - Vol. 11 (3). - P. 646.

20. Heart rate variability as a marker of recovery from critical illness in children / L. E. Marsillio, T. Manghi, M. S. Carroll [et. al] // Plos One. - 2019. - Vol. 14 (5). - P. e0215930.

21. Plasma vitamin B12, methylmalonic acid and heart rate variability in healthy young Indian adults / S. Sucharita, S. Sowmya, T. Thomas [et al.] // Int. J. Vitam. Nutr. Res. - 2013. - Vol. 83 (3). - P. 147-153.

9. Pektas, A., Koken, R., \& Koca, H.B. (2018). Serum vitamin $\mathrm{B}-12$ in children presenting with vasovagal syncope. Asia Pac. J. Clin. Nutr., 27 (1), 176-181. DOI: 10.6133/apjcn.022017.17.

10. Brignole, M., Moya, A., de Lange, F.J., Deharo, J.C., Elliott, P.M., Fanciulli, A., ..., \& van Dijk, J.G. (2018). 2018 ESC Guidelines for the diagnosis and management of syncope. Eur. Heart J., 39 (21), 1883-1948. DOI: 10.1093/eurheartj/ehy037.

11. Tanaka, H., Fujita, Y., Takenaka, Y., Kajiwara, S., Masutani, S., Ishizaki, Y., ..., \& Honda,, K. (2009). Japanese clinical guidelines for juvenile orthostatic dysregulation version 1. Pediatr. Int., 51 (1), 169-179. DOI: 10.1111/j.1442200X.2008.02783.x.

12. Huemer, M., Vonblon, K., Födinger, M., Krumpholz, R., Hubmann, M., Ulmer, H., \& Simma, B. (2006). Total homocysteine, folate, and cobalamin, and their relation to genetic polymorphisms, lifestyle and body mass index in healthy children and adolescents. Pediatr. Res., 60 (6), 764-769. DOI: 10.1203/01.pdr.0000246099.39469.18.

13. Berezhnoy, V.V., \& Romankevych, I.V. (2015). Zastosuvannia vyznachennia variabelnosti sertsevoho rytmu u ditei [Using heart rate variability study in children]. Sovremennaya pedyatriya - Modern Pediatrics, 1 (65), 87-91. DOI 10.15574/SP.2015.65.87 [in Ukrainian].

14. Parati, G., Stergiou, G., O'Brien, E., Asmar, R., Beilin, L., Bilo, G., ..., \& Zhang, Y. (2014). European Society of Hypertension practice guidelines for ambulatory blood pressure monitoring. J. Hypertens, 32 (7), 1359-1366. 
15. Kovalchuk, T.A. (2020). Osoblyvosti profiliu vitaminu B6 $u$ ditei ta pidlitkiv iz vazovahalnymy syncope [Features of vitamin B6 profile in children and adolescents with vasovagal syncope] Suchasna pediatriia. Ukraina - Modern Pediatrics. Ukraine, 4 (108), 61-66. DOI 10.15574/SP.2020.108.61 [in Ukrainian].

16. van Oijen, M.G., Laheij, R.J., Jansen, J.B., \& Verheugt, F.W. (2007). The predictive value of vitamin B12 concentrations and hyperhomocysteinaemia for cardiovascular disease. Neth. Heart J., 15 (9), 291-294. DOI: 10.1007/BF03086002.

17. Polytarchou, K., Dimitroglou, Y., Varvarousis, D., Christodoulis, N., Psachoulia, C., Pantziou, C., ..., \& Manolis, A.S. (2020). Methylmalonic acid and vitamin B12 in patients with heart failure. Hellenic J. Cardiol., 61 (5), 330-337. DOI: 10.1016/j.hjc.2019.10.010.

18. Marcucci, R., Betti, I., Cecchi, E., Poli, D., Giusti, B., Fedi, S., ..., \& Prisco, D. (2004). Hyperhomocysteinemia and vitamin
B6 deficiency: new risk markers for nonvalvular atrial fibrillation? Am. Heart J., 148 (3), 456-461. DOI: 10.1016/j.ahj.2004.03.017.

19. Caldeira-Araújo, H., Ramos, R., Florindo, C., Rivera, I., Castro, R., \& Tavares de Almeida, I. (2019). Homocysteine metabolism in children and adolescents: influence of age on plasma biomarkers and correspondent genotype interactions. Nutrients, 11 (3), 646. DOI: 10.3390/nu11030646.

20. Marsillio, L.E., Manghi, T., Carroll, M.S., Balmert, L.C., \& Wainwright, M.S. (2019). Heart rate variability as a marker of recovery from critical illness in children. PloS One, 14 (5), e0215930. DOI: 10.1371/journal.pone.0215930.

21. Sucharita, S., Sowmya, S., Thomas, T., Kurpad, A.V., \& Vaz, M. (2013). Plasma vitamin B12, methylmalonic acid and heart rate variability in healthy young Indian adults. Int. J. Vitam. Nutr. Res., 83 (3), 147-153.

Отримано 14.04.21 Прийнято до друку 17.05.21 Електронна адреса для листування: tetianakovalchuk@gmail.com 